\title{
Yaupon and Associated Vegetation Response to Seasonal Tebuthiuron Applications
}

\author{
K.W. DUNCAN AND C.J. SCIFRES
}

\section{Abstract}

Broadcast applications of tebuthiuron pellets (20\% active ingredient [a.i.]) at $2 \mathrm{~kg} / \mathrm{ha}$ (a.i.) in spring more effectively controlled yaupon than applications in summer, fall or winter on the Post Oak Savannah. Tebuthiuron applications in spring reduced the live canopy of yaupon by $80 \%$. Tebuthiuron at $1 \mathrm{~kg} / \mathrm{ha}$ díd not effectively control yaupon, regardless of season of treatment. Herbaceous response to tebuthiuron was relatively slow because of lack of a seed source in the heavy yaupon covers. However, by December 1980 after applications of tebuthiuron at 2 or $4 \mathrm{~kg} / \mathrm{ha}$ in spring or summer 1978, grass standing crops were significantly increased. Forb standing crops were highly variable, but there was no apparent forb reduction in 1980 of 1981 where herbicide was applied in 1978-1979.

Yaupon (Ilex vomitoria Ait.), an evergreen number of the holly family (Aquifoliaceae), occurs throughout the Coastal Plain from southeast Virginia to central Florida and westward to eastern and southcentral Texas (Vines 1960). Yaupon occurs on approximately 1 million ha in Texas and canopy cover of about $40 \%$ of the stands are greater than 20\% (Smith and Rechenthin 1964). Although yaupon is excellent browse for white-tailed deer (Odocoileus virginianus L.) (Halls 1977) and is browsed by cattle (Lehman and Davis 1966), dense cover essentially precludes development of herbaceous forage stands.

Yaupon is a serious range management problem on moist, sandy sites in the Post Oak Savannah, 3.5 million ha of gently rolling to hilly lands in east central Texas (Scifres 1980). Two successive annual applications of $2.2 \mathrm{~kg} /$ ha of $2,4,5-\mathrm{T}$ (2,4,5-trichlorophenoxy)-acetic acid] usually kills $75 \%$ of post oaks (Quercus stellata Wang.) and blackjack oaks (Quercus marilandica Muenchh.) (Lehman and Davis 1966). However, yaupon normally resists this treatment, and stands may dramatically increase in density and canopy cover following oak control (Scifres 1980).

Picloram (4-amino-3,5,6-trichloropicolinic acid) pellets or sprays applied broadcast at $2.2 \mathrm{~kg} / \mathrm{ha}$ appear promising for yaupon control (Bovey et al. 1969, 1972; Scifres and Haas 1974), but hexazinone [2-cyclohexyl-6-dimethylamino)-1-methyl-1,3,5triazine-2,4(1 H, 3H-dione)] at rates to $4 \mathrm{~kg} /$ ha does not appear effective against yaupon (Scifres 1982).

Scifres et al. (198I) reported that aerial applications of 2 or 4 $\mathrm{kg} / \mathrm{ha}$ (a.i.) of tebuthiuron [N-(5-[1,1-dimethylethyl]-1,3,4thiadiazol-2-yl)- $N, N^{\prime \prime}$ dimethylurea] as the $20 \%$ pellets in spring effectively controlled yaupon. However, efficacy of rates less than $2 \mathrm{~kg} / \mathrm{ha}$ and applied at various seasons specifically for yaupon control has not been reported.

Objectives of this research were to determine the efficacy of 1,2, and $4 \mathrm{~kg} /$ ha of tebuthiuron pellets applied seasonally for yaupon control, and herbaceous response to yaupon control with tebuthiuron.

\footnotetext{
Authors are former research assistant and professor, Texas Agricultural Experiment Station (Department of Range Science). Texas A\&M University, College Station, 77843. Duncan's present address is Lilly Research Laboratories, P.O. Box 344789, Farmers Branch, Texas 75234. Approved by the Director, Texas Agricultural Experiment Station as TA-17698. Authors greatly appreciate the assistance of M.A. Foster. G.A. Rasmussen, R.P. Smith, R.A. Masters, and T. W. Oldham in installation and evaluation of experiments; and of Julia Scifres in manuscript preparation and typing.

Manuscript received May 20, 1982.
}

\section{Materials and Methods}

Experiments were located on the Texas A\&M University Native Plant and Animal Conservancy approximately $3 \mathrm{~km}$ southwest of College Station. Annual rainfall on the study area averages $94 \mathrm{~cm}$. Soils of the experimental areas were Lufkin fine sandy loam (Vertic Albaqualf). Lufkin series, common to Claypan Savannah range sites, has a sandy loam layer less than $24 \mathrm{~cm}$ thick over a tight clay subsoil.

Experiments were established in dense stands of yaupon under large post oaks. Species composition of woody plant stands on the general study site has been given by Scifres et al. (1981). Two completely random experiments arranged as split plots with 4 replications were established about $1 \mathrm{~km}$ apart. Season of application constituted main-plot effect and tebuthiuron rate as subplot effect. Tebuthiuron at $0,1,2$ or $4 \mathrm{~kg} /$ ha was applied with a hand-operated spreader to $15.3-$ by $15.3-\mathrm{m}$ sub-plots separated by 15 -m-wide buffers in spring (April 12, 1978), summer (July 25, 1978), fall (October 18, 1978) or winter (February 16, 1979).

Permanent sampling areas, $0.6 \mathrm{~m}$ wide, were established on the diagonal across each plot. Number of live yaupon stems rooted in the sampling areas were counted at the times of tebuthiuron application and in May, July, November, and December 1979; February, April, and August 1980; and in December 1981. Yaupon stems were categorized as "small" ( $\leq 1.8 \mathrm{~m}$ tall) or "large" $>1.8 \mathrm{~m}$ tall), except at the last sampling. Yaupon live canopy intercepts along a line in the center of the sampling areas were recorded on each sampling date.

Post-treatment live yaupon stem densities and canopy intercepts were converted to percentages of pretreatment values which were transformed to the arc-sine (Steel and Torrie 1980) before cond ucting analyses of variance. Means were separated $(P \leq .05)$ by Student-Newman-Keul's test.

Basal cover of herbaceous vegetation by species was determined from 18 inclined 10-point frames equally spaced along each line across the center of each plot on every sampling date except the last. Standing herbaceous crops were harvested from 5 , randomly placed, $0.25-\mathrm{m}^{2}$ sampling a reas in each subplot on December 5 , 1980 , and on December 15, 1981. The vegetation was separated into grasses, grasslike plants or broadleaved plants, dried at $100^{\circ} \mathrm{C}$ for $24 \mathrm{hr}$, and weighed. Data were subjected to analysis of variance and means separated according to Student-Newman-Keul's test $(\leq .05)$.

A rain gauge was established on each experimental area. In addition, precipitation was measured with a continuously recording rain gauge within $24 \mathrm{~m}$ of the experiments.

Soil was collected from 0 to 8 and 8 to $15 \mathrm{~cm}$ deep from the center of every third plot in a grid across the experiments at the time of herbicide application. Soils were analyzed for water content gravimetrically, textural components by the hydrometer method (Day 1956), organic-matter content by the Walkley-Black method (Black 1965), and pH of a 1:1 slurry.

\section{Results and Discussion}

Soils over the experimental area varied from silty clay to sandy 
Table 1. Organic matter contents, pH and proportions of textural components at 2 depths by seasons of tebuthiuron application during $1978-1979$ to stands of yaupon near College Station, Texas.

\begin{tabular}{|c|c|c|c|c|c|c|c|}
\hline $\begin{array}{l}\text { Season of tebuthiuron } \\
\text { application }\end{array}$ & $\begin{array}{l}\text { Soil depth } \\
\text { (cm) }\end{array}$ & $\mathrm{pH}$ & $\begin{array}{c}\text { Organic matter } \\
(\%)\end{array}$ & $\begin{array}{l}\text { Sand } \\
(\%)\end{array}$ & $\begin{array}{l}\text { Silt } \\
(\%)\end{array}$ & $\begin{array}{l}\text { Clay } \\
(\%)\end{array}$ & Texture ${ }^{1}$ \\
\hline & & & & perime & & & \\
\hline \multirow[t]{2}{*}{ Spring } & $0-8$ & 5.4 & 3.9 & 61 & 33 & 6 & sil \\
\hline & $8-15$ & 5.3 & 1.1 & 61 & 31 & 8 & sil \\
\hline \multirow[t]{2}{*}{ Summer } & $0-8$ & 5.5 & 1.8 & 65 & 27 & 8 & sl \\
\hline & $8-15$ & 4.5 & 2.9 & 46 & 27 & 27 & ]-sil \\
\hline \multirow[t]{2}{*}{ Fall } & $0-8$ & 5.8 & 3.4 & 35 & 40 & 25 & sil \\
\hline & $8-15$ & 5.2 & 2.0 & 25 & 34 & 41 & sic \\
\hline \multirow[t]{3}{*}{ Winter } & $0-8$ & 5.7 & 4.5 & 33 & 35 & 32 & sicl \\
\hline & $8-15$ & 5.4 & 2.5 & 30 & 30 & 40 & sic \\
\hline & \multicolumn{7}{|c|}{ Experiment 2} \\
\hline \multirow[t]{2}{*}{ Spring } & $0-8$ & 5.6 & 3.2 & 62 & 32 & 6 & sl \\
\hline & $8-15$ & 5.2 & 1.4 & 58 & 31 & 11 & sl \\
\hline \multirow[t]{2}{*}{ Summer } & $0-8$ & 5.9 & 2.4 & 59 & 30 & 11 & sl \\
\hline & $8-15$ & 4.9 & 1.1 & 50 & 27 & 23 & 1 \\
\hline \multirow[t]{2}{*}{ Fall } & $0-8$ & 5.8 & 3.1 & 56 & 31 & 13 & sl-1 \\
\hline & $8-15$ & 5.3 & 1.5 & 48 & 28 & 24 & 1 \\
\hline \multirow[t]{2}{*}{ Winter } & $0-8$ & 6.1 & 3.1 & 67 & 27 & 6 & sl \\
\hline & $0-15$ & 5.7 & 1.8 & 65 & 27 & 8 & sl \\
\hline
\end{tabular}

'Sil=silty loam, sl-sandy loam, l-loam, sic-silty clay, sicl-silty clay loam.

loam and organic matter contents in the surface $8 \mathrm{~cm}$ varied from 1.8 to $4.5 \%$ (Table 1). The greatest difference in soil textures between experiments within dates of tebuthiuron application occurred with winter and fall treatments (Table 1). For example, tebuthiuron was applied in winter to soils containing $32 \%$ clay in the surface $8 \mathrm{~cm}$ in one experiment compared to only $6 \%$ clay content on the other site. Soils where tebuthiuron was applied in spring or summer were generally silty loams to sandy loams for both experiments. Influence of season of treatment, tebuthiuron rate, and interaction of rate and season were usually significant $(P \leq .05)$, and apparently masked the influence of soils. However, variation attributable to season of application by experiment was not significant, regardless of date of evaluation or response variable (canopy cover reduction, stem density reduction). Therefore, response data were averaged across experiments for presentation.

Greatest reductions of yaupon live canopy at 12 to 13 months

Table 2. Percentage reductions in live canopy covers and densities of live stems by size category at 12 to 13 months following broadeast applications of tebuthiuron pellets in the spring, summer or fall 1978 or winter 1979 near College Station, Texas.'

\begin{tabular}{|c|c|c|c|c|}
\hline \multirow{2}{*}{$\begin{array}{l}\text { Tebuthiuron rate } \\
\text { (kg/ha) }\end{array}$} & \multicolumn{4}{|c|}{ Season of tebuthiuron application ${ }^{2}$} \\
\hline & Spring & Summer & Fall & Winter \\
\hline $\begin{array}{l}0 \\
1 \\
2 \\
4\end{array}$ & $\begin{array}{c}(+6) \mathrm{h} \\
46 \mathrm{~cd} \\
75 \mathrm{ab} \\
92 \mathrm{a}\end{array}$ & $\begin{array}{l}\text { Live ca } \\
2 \mathrm{gh} \\
11 \mathrm{e}-\mathrm{h} \\
35 \mathrm{c}-\mathrm{f} \\
46 \mathrm{~cd}\end{array}$ & $\begin{array}{l}\text { py cover } \\
36 \mathrm{e}-\mathrm{f} \\
49 \mathrm{bcd} \\
40 \mathrm{cde} \\
56 \mathrm{bc}\end{array}$ & $\begin{array}{l}20 \mathrm{~d}-\mathrm{h} \\
9 \mathrm{fgh} \\
28 \mathrm{c}-\mathrm{g} \\
54 \mathrm{bc}\end{array}$ \\
\hline $\begin{array}{l}0 \\
1 \\
2 \\
4\end{array}$ & $\begin{array}{r}(+5) \mathrm{a} \\
3 \mathrm{a} \\
3 \mathrm{a} \\
39 \mathrm{a}\end{array}$ & $\begin{array}{c}\text { Larg } \\
(+55) \mathrm{b} \\
(+79) \mathrm{b} \\
13 \mathrm{a} \\
19 \mathrm{a}\end{array}$ & $\begin{array}{r}\text { stems }^{3} \\
0 \mathrm{a} \\
(+9) \mathrm{a} \\
(+17) \mathrm{a} \\
18 \mathrm{a}\end{array}$ & $\begin{array}{r}(+12) \mathrm{a} \\
8 \mathrm{a} \\
26 \mathrm{a} \\
37 \mathrm{a}\end{array}$ \\
\hline $\begin{array}{l}0 \\
1 \\
2 \\
4\end{array}$ & $\begin{array}{c}(+3) \mathrm{ijk} \\
20 \mathrm{cde} \\
17 \mathrm{de} \\
62 \mathrm{a}\end{array}$ & $\begin{array}{c}(+30) \mathrm{l} \\
29 \mathrm{bcd} \\
29 \mathrm{bcd} \\
46 \mathrm{ab}\end{array}$ & $\begin{array}{c}\text { mall stems } \\
15 \mathrm{def} \\
\begin{array}{c}(+8) \mathrm{jk} \\
3 \mathrm{e}-\mathrm{h} \\
37 \mathrm{bc}\end{array}\end{array}$ & $\begin{array}{r}(+12) \mathrm{kl} \\
(+15) \mathrm{kl} \\
8 \mathrm{efg} \\
44 \mathrm{ab}\end{array}$ \\
\hline
\end{tabular}

IMeans within a response variable and followed by the same letter are not significantly $(P \leq .05)$ different according to Student-Newman-Keul's test.

${ }_{2}$ Positive values in parenthesis indicate an increase compared to pretreatment value. ${ }^{3}$ Large yaupon stems were $<1.8 \mathrm{~m}$ tall and small stems were $\leq 1.8 \mathrm{~m}$ tall at time of evaluation. after tebuthiuron application occurred from treatments in spring, especially where 2 or $4 \mathrm{~kg} / \mathrm{ha}$ were applied (Table 2). Soil water contents ranged from $0.2 \%$ in the surface $3 \mathrm{~cm}$ to $2.7 \%$ at 8 to $15 \mathrm{~cm}$ deep when tebuthiuron was applied in spring. Rainfall occurred within 12 days following applications in spring, and by first evaluation 13 months later, the areas had received $138 \mathrm{~cm}$ of rainfall. Live yaupon canopy reduction 13 months after tebuthiuron application of $4 \mathrm{~kg} / \mathrm{ha}$ in fall or winter was roughly equivalent to $2 \mathrm{~kg} / \mathrm{ha}$ applied in spring (Table 2). Application of $2 \mathrm{~kg} /$ ha of tebuthiuron in summer, fall, winter resulted in live yaupon canopy reduction equivalent to that following application of $1 \mathrm{~kg} / \mathrm{ha}$ in spring.

Tebuthiuron did not kill a significant proportion of the large yaupon stems $>1.8 \mathrm{~m}$ tall) by 1 year after application, regardless of herbicide rate or season of treatment (Table 2); and, density of large stems increased on untreated areas and on those which were treated with $1 \mathrm{~kg} / \mathrm{ha}$ of tebuthiuron in summer. Tebuthiuron at 4 $\mathrm{kg} /$ ha significantly reduced the live density of small ( $\leq 1.8 \mathrm{~m}$ tall) yaupon stems after 1 year at all seasons of application, compared to the respective untreated plots.

Based on evaluations at 22 to 24 months after application, 1 $\mathrm{kg} / \mathrm{ha}$ of tebuthiuron did not effectively control yaupon (Table 3 ). Tebuthiuron at $2 \mathrm{~kg} /$ ha was most effective after applications in spring, and greatest reduction in live yaupon canopy and stem densities from $4 \mathrm{~kg} / \mathrm{ha}$ occurred after application in spring or summer.

Results from tebuthiuron applications in spring in this study were similar to those reported by Scifres et al. (1981). They reported yaupon canopy reductions to exceed $90 \%$ at 26 to 36 months after application of tebuthiuron at $2.2 \mathrm{~kg} / \mathrm{ha}$. Canopy reduction averaged $80 \%$ at 43 months after spring applications of 2 $\mathrm{kg} / \mathrm{ha}$ in these experiments (Table 4), whereas applications of 2 $\mathrm{kg} / \mathrm{ha}$ in summer, fall or winter reduced live yaupon canopy cover by only 11 to $40 \%$.

Reasons for more effective yaupon control when tebuthiuron was applied in spring, compared to application at other seasons, are not clear. Although there was no experiment by season of application interaction which would have implicated differences in soil characteristics as influential on yaupon response (and which would be expected considering differences in clay contents between experiments where tebuthiuron was applied in winter), potential influence of soil variations is difficult to ignore. Average clay contents were $8 \%$ on sites treated in spring compared to 17,26 and $22 \%$, respectively, where tebuthiuron was applied in summer, fall or winter. Variations were minor but there was a tendency for soils 
Table 3. Percentage reductions in live canopy cover and densities of live atems by size category at 22 to 24 months following broadcast applications of tebuthiuron in the spring, summer or fall 1978 or winter 1979 near Colleze Station, Texas. 1

\begin{tabular}{lcccc}
\hline \hline $\begin{array}{l}\text { Tebuthiuron rate } \\
(\mathrm{kg} / \mathrm{ha})\end{array}$ & \multicolumn{4}{c}{ Season of tebuthiuron application ${ }^{2}$} \\
\cline { 2 - 6 } 0 & Spring & Summer & Fall & Winter \\
\hline & $(+12) \mathrm{g}$ & $1 \mathrm{fg}$ & $\begin{array}{c}\text { Canopy Cover } \\
17 \mathrm{def}\end{array}$ & $(+8) \mathrm{g}$ \\
1 & $24 \mathrm{de}$ & $10 \mathrm{ef}$ & $28 \mathrm{~cd}$ & $2 \mathrm{fg}$ \\
2 & $77 \mathrm{~b}$ & $30 \mathrm{~cd}$ & $34 \mathrm{~cd}$ & $10 \mathrm{ef}$ \\
4 & $94 \mathrm{a}$ & $80 \mathrm{a}$ & $54 \mathrm{~b}$ & $45 \mathrm{bc}$ \\
& & & $\mathrm{Large} \mathrm{stems}$ & \\
0 & $16 \mathrm{~cd}$ & $(+34) \mathrm{fg}$ & $(+45) \mathrm{g}$ & $(+3) \mathrm{de}$ \\
1 & $(+10) \mathrm{e}$ & $(+12) \mathrm{ef}$ & $(+34) \mathrm{fg}$ & $(+5) \mathrm{de}$ \\
2 & $75 \mathrm{a}$ & $53 \mathrm{bc}$ & $13 \mathrm{~d}$ & $34 \mathrm{c}$ \\
4 & $75 \mathrm{a}$ & $80 \mathrm{a}$ & $52 \mathrm{bc}$ & $66 \mathrm{ab}$ \\
& & & $\mathrm{Small} \mathrm{stems}$ & \\
0 & $7 \mathrm{ghi}$ & $(+10) \mathrm{ij}$ & $15 \mathrm{fgh}$ & $(+2) \mathrm{hij}$ \\
1 & $39 \mathrm{de}$ & $29 \mathrm{ef}$ & $(+13) \mathrm{j}$ & $11 \mathrm{fgh}$ \\
2 & $58 \mathrm{bc}$ & $40 \mathrm{~cd}$ & $7 \mathrm{ghi}$ & $18 \mathrm{fg}$ \\
4 & $94 \mathrm{a}$ & $73 \mathrm{~b}$ & $51 \mathrm{~cd}$ & $48 \mathrm{~cd}$ \\
\hline
\end{tabular}

'Means within a response variable and followed by the same letter are not significantly $(P \leq .05)$ different according to Student-Newman-Keul's test.

2Positive values in parenthesis indicate an increase compared to pretreatment value. ${ }^{3}$ Large yaupon stems were $>1.8 \mathrm{~m}$ tall and small stems were $\leq 1.8 \mathrm{~m}$ tall at the time of evaluation.

of sites treated in winter to contain greater amounts of organic matter than those treated at other seasons.

Differences in precipitation following tebuthiuron applications did not appear adequate to favor increased herbicide activity after application in spring, compared to other seasons. For example, rainfall for the first 3 months after treatment totaled $21 \mathrm{~cm}$ for applications in spring, $20 \mathrm{~cm}$ for summer, 35 following treatments in fall, and 38 following those in winter. Since yaupon is an evergreen, applications of tebuthiuron in spring should not necessarily improve control, compared to fall, on the basis of need for active vegetative growth to stimulate herbicide uptake.

Pretreatment herbaceous stands were composed primarily of shade-tolerance species such as longleaf chasmanthium (Chasmanthium latifolium [Michx.] Yates) and low-growing annuals. No grasses existed on more than half of the plots at the time of treatment. By the year after applications of tebuthiuron in spring or summer, grass basal cover ranged from 0.1 to $2.4 \%$, compared to no contact with grasses or untreated plots or where the herbicide has been applied in the fall or winter (data not shown).

Standing crops of grasses in December 1980 were greater on plots treated with tebuthiuron in spring or summer 1978 than on untreated plots (Table 5). Although rainfall in $1978(84 \mathrm{~cm}$ ) was
Table 4. Percentage reductions in live canopy cover on December 11,1981, 34 to $\mathbf{4 3}$ months following broadcast applications of tebuthiuron in the spring, summer or fall 1978 or winter 1979 near College Station, Texas.'

\begin{tabular}{lcrrr}
\hline \hline \multirow{2}{*}{$\begin{array}{l}\text { Tebuthiuron rate } \\
(\mathrm{kg} / \mathrm{ha})\end{array}$} & \multicolumn{4}{c}{ Season of tebuthiuron application } \\
\cline { 2 - 5 } & Spring & Summer & \multicolumn{1}{c}{ Fall } & \multicolumn{1}{c}{ Winter } \\
\hline 0 & $(+29) \mathrm{i}$ & $(+2) \mathrm{ghi}$ & $(+5) \mathrm{ghi}$ & $(+14) \mathrm{hi}$ \\
1 & $34 \mathrm{ef}$ & $11 \mathrm{fgh}$ & $23 \mathrm{efg}$ & $(+7) \mathrm{ghi}$ \\
2 & $80 \mathrm{ab}$ & $33 \mathrm{def}$ & $40 \mathrm{def}$ & $11 \mathrm{fgh}$ \\
4 & $89 \mathrm{a}$ & $69 \mathrm{abc}$ & $56 \mathrm{bcd}$ & $43 \mathrm{cde}$ \\
\hline
\end{tabular}

1 Means followed by the same letter are not significantly different $(P \leq .05)$ according to Student-Newman-Keul's test.

${ }_{2}^{2}$ Positive values in parenthesis indicate an increase compared to the original canopy cover.

less than the long-term average, rainfall in $1979(141 \mathrm{~cm})$ was $150 \%$ of the annual average. Applications of tebuthiuron in fall did not increase grass standing crops, and grass standing crops were increased from winter application only by the higher herbicide rate. Forb standing crops in December 1980, composed primarily of western ironweed (Vernonia baldwini), were increased where tebuthiuron was applied at $4 \mathrm{~kg} / \mathrm{ha}$ in spring, summer or fall, compared to forb standing crops on untreated areas.

Basal cover of herbaceous vegetation ranged from 1.6 to $3.6 \%$ on plots treated in spring, compared to $0.4 \%$ on untreated plots, at 18 to 20 months after herbicide application (data not shown). Basal herbaceous cover on plots treated with tebuthiuron in summer ranged from 0.1 to $1.1 \%$, compared to no contacts with herbaceous vegetation on untreated plots. Cover of herbaceous vegetation was less than $0.1 \%$ at 18 to 20 months after application of tebuthiuron in fall or winter.

Grass standing crops were increased by December 1981, compared to untreated areas, where $2 \mathrm{~kg} /$ ha were applied in spring or summer, and where $4 \mathrm{~kg} /$ ha had been applied in spring, summer or winter (Table 5). Grass standing crops tended to be only slightly increased where $1 \mathrm{~kg} /$ ha of tebuthiuron was applied, regardless of season of treatment. Forb standing crops were highly variable by December 1981, but were not decreased by herbicide application.

Lack of a grass source for establishment after tebuthiuron application to this site apparently explains the relatively slow improvement in forage cover and production. Scifres et al. (1981) reported that maximum forage production might not occur for more than 3 growing seasons on sites so seriously depleted of herbaceous cover. A trend toward improvement of the forage stand was evidenced in December 1981 when the majority of the standing crop was little bluestem (Schizachyrium scoparium[Michx.] Nash).

\section{Literature Cited}

Black, G.R. 1965. Particle density. p. 371-373, In: Black, Ed. Methods of Soil Analysis. Amer. Soc. Agron., Inc. Madison, Wisc.

Table 5. Oven-dry standing crops (kg/ha) of grasses and broadleaved herbaceous vegetation on December 5, 1980, and December 15, 1981, following applications of tebuthiuron in the spring, summer or fall 1978 or winter 1979 to yaupon stands near College Station, Texas.

\begin{tabular}{|c|c|c|c|c|c|c|c|c|}
\hline \multirow{2}{*}{$\begin{array}{l}\text { Tebuthiuron rate } \\
\text { (kg/ha) }\end{array}$} & \multicolumn{8}{|c|}{ Season of tebuthiuron application ${ }^{t}$} \\
\hline & Spring & Summer & Fall & Winter & Spring & Summer & Fall & Winter \\
\hline \multirow{3}{*}{$\begin{array}{l}0 \\
1 \\
2 \\
4\end{array}$} & \multicolumn{8}{|c|}{ Grasses } \\
\hline & $\begin{array}{r}120 \mathrm{a} \\
980 \mathrm{~b} \\
1780 \mathrm{~d} \\
2340 \mathrm{e}\end{array}$ & $\begin{array}{l}\quad 60 a \\
1400 c \\
1200 b c \\
2320 e\end{array}$ & $\begin{array}{r}320 \mathrm{a} \\
20 \mathrm{a} \\
60 \mathrm{a} \\
40 \mathrm{a}\end{array}$ & $\begin{array}{r}0 \mathrm{a} \\
0 \mathrm{a} \\
20 \mathrm{a} \\
1220 \mathrm{bc}\end{array}$ & $\begin{array}{c}48 \mathrm{ab} \\
192 \mathrm{abc} \\
1105 \mathrm{e} \\
1351 \mathrm{f}\end{array}$ & $\begin{array}{c}84 \mathrm{abc} \\
253 \mathrm{abc} \\
638 \mathrm{~d} \\
1184 \mathrm{ef}\end{array}$ & $\begin{array}{l}30 \mathrm{ab} \\
188 \mathrm{abc} \\
176 \mathrm{abc} \\
320 \mathrm{~cd}\end{array}$ & $\begin{array}{c}7 \mathrm{a} \\
18 \mathrm{ab} \\
157 \mathrm{abc} \\
1021 \mathrm{e}\end{array}$ \\
\hline & & & & \multicolumn{2}{|c|}{ Forbs } & $\cdot$ & & \\
\hline $\begin{array}{l}0 \\
1 \\
2 \\
4\end{array}$ & $\begin{array}{l}40 \mathrm{ab} \\
200 \mathrm{ab} \\
400 \mathrm{bc} \\
560 \mathrm{c}\end{array}$ & $\begin{array}{c}20 \mathrm{a} \\
40 \mathrm{ab} \\
120 \mathrm{ab} \\
1020 \mathrm{~d}\end{array}$ & $\begin{array}{l}20 a \\
20 a \\
40 a b \\
240 \mathrm{~b}\end{array}$ & $\begin{array}{c}0 \mathrm{a} \\
0 \mathrm{a} \\
0 \mathrm{a} \\
80 \mathrm{ab}\end{array}$ & $\begin{array}{l}10 a \\
24 a b \\
16 a \\
28 a b\end{array}$ & $\begin{array}{c}5 a \\
7 a \\
11 a \\
49 a b c\end{array}$ & $\begin{array}{c}34 a b c \\
14 a \\
89 c \\
160 d\end{array}$ & $\begin{array}{c}4 a \\
9 a \\
79 \mathrm{bc} \\
512 \mathrm{e}\end{array}$ \\
\hline
\end{tabular}

I Means within a standing crop ca tegory and within a year of evaluation followed by the same letter are not significantly different $(P \leq .05)$ according to Student-Newman-Keul's test. 
Bovey, R.W., H.L. Morton, J.R. Baur, J.D. Diaz-Colon, C.C. Dowler, and S.K. Lehman. 1969. Granular herbicides for woody plant control. Weed Sci. 16:583-641.

Bovey, R.W., H.L. Morton, R.E. Meyer, T.O. Flynt, and T.E. Riley. 1972 Control of yaupon and associated species. Weed Sci. 20:246-249.

Day, P.R. 1956. Report of the committee on Physical Analysis. Soil Sci. Soc. Amer. Proc. 21:662.

Halls, L.K. 1977. Southern fruit producing woody plants used by wildlife U.S. Dep. Agr., Forest Serv. Gen. Tech. Rep. SO-16.

Lehman, S.K., and F.S. Davis. 1966. Chemical control of yaupon (llex vomitoria ait.). Proc. So. Weed Conf. 19:287-294.

Scifres, C.J. 1980. Brush Management. Texas A\&M Univ. Press. College Station, Texas.
Scifres, C.J. 1982. Woody plant control in the post oak savannah of Texas with hexazinone. J. Range Manage. 35:

Scifres, C.J., and R.H. Haas. 1974. Vegetational changes in a post oak savannah following woody plant control. Tex. Agr. Exp. Sta. Misc. Pub. 1136.

Sclfres, C.J., J.W. Stuth, and R.W. Bovey. 1981. Control of oaks (Quercus spp.) and associated woody species on rangeland with tebuthiuron. Weed Sci. 29:270-275.

Smith, H.N., and C.A. Rechenthin. 1964. Grassland restoration-the Texas brush problem. USDA, SCS. Unnumbered Bull.

Steel, R.G.D, and J.H. Torrie. 1980. Principles and Proced ures of Statistics (2nd Ed.). McGraw-Hill Book Co., New York.

Vines, R.A. 1960. Trees of East Texas. University of Texas Press. Austin and London. 